\title{
KOMBINASI CAMPURAN LIMBAH MOULDING DAN KAYU HTI UNTUK PELLET KAYU SEBAGAI BAHAN BAKAR ALTERNATIF
}

\author{
Oleh : \\ Suroto $\mathrm{HS}^{\text {1) }}$ \\ Yuliansyah $^{2)}$
}

\begin{abstract}
Eventhough the poteify waste into wood savinncy of timber and the number of active moulding industries are deccreasing racently, the demand of moulding products is still hight. Actually the waste of moulding can be utillized for fuel but the waste must be treated previosly. The treatment is to classify waste into wood saving, wood planing and sawdust. The size wood saving and wood planing ware reduced by using a hammermill, after that the wastes were screened. while the sawdust was screened directly. Them, all screened wood were combined wiht the screened wood from timber estate. All of these materials were mixed together with cassava glue. Pellet is an alternative source of fuel. The quality of produced pellet is $0,49-0,80$ $\mathrm{gr} / \mathrm{cm} 3$ for density parameter, $2.40-9.64 \%$ for moisture content, and $0.15-1.08 \%$ for ash content. These properties meet the requirements of national and international market. How ever. parameter of gross caloric value of pellet, which was $4042-4380$ callg. did not meet the requirements.
\end{abstract}

Keywords: combinastion, moulding waste, timber estate wood, and pellet

\section{PENDAHULUAN}

$\mathrm{M}$

inyak tanah sampai saat ini masih menjadi sumber energi utama untuk keperluan rumah tangga dan industri rumah tangga, di sisi lain bahwa cadangan bahan bakar minyak semakin menyusut. Industri moulding yang memproduksi lembaran papan, kosen dan produk lainnya yang cukup besar peminatnya baik dari dalam negeri (domestik) maupun pasar ekspor (luar negeri). Dalam proses penggergajian, serutan, plener dan pemotongan pada industri sawmill maupun moulding selain yang dihasilkan adalah produk utama juga ada hasil samping yaitu berupa limbah serbuk gergaji, serutan dan tatalan kecil. Kayu-kayu yang diolah oleh industri moulding berasal dari alam diantaranya adalah ulin, bengkirai, krueng, kapur dan meranti.

Berdasarkan pengalaman dari proses moulding limbah yang diperoleh mencapai $25 \%$ dari volume kayu yang diolah. Jika kayu yang diolah sekitar $100 \mathrm{~m}^{3}$ per hari maka akan diperoleh limbah sekitar $25 \mathrm{~m}^{3}$. Jika dalam satu bulan bekerja 25 hari maka akan diperoleh limbah sebesar $625 \mathrm{~m}^{3}$. Potensi kayu alam saat ini makin berkurang, untuk memenuhi kekurangan akan kebutuhan kayu alam tersebut digalakkan menanam kayu yang berumur pendek (Hutan Tanaman Industri (HTI) diantaranya berupa kayu sengon, gmelina, dan akasia. Dalam proses pemanenan kayu-kayu tersebut dimanfaatkan hanya

\footnotetext{
1) Penelth Muda Banistand irdustri Samaninda

2) Dasen Fakutgs Kehitaran UNMUL Samarindo
} 
berupa batang dengan batas panjang tertentu. Sehingga masih terdapat sisa potongan dari proses pemanenan tersebut berupa sisa batang kayu, cabang dan ranting yang merupakan limbah.

Agar dalam proses produksi moulding dan proses pemanenan kayu hutan tanaman industri terjadi produksi bersih (pemamnfaatan bahan secara optimal) maka langkah yang ditempuh adalah memanfaatkan limbah dari proses penggergajian, plener, serutan, dan pemotongan dijadikan sebagai bahan bakar alternatif berupa pellet kayu dengan tujuan mendapatkan kombinasi campuran limbah moulding dan kayu Hutan Tanaman Industri terbaik untuk produk pellet kayu.

\section{BAHAN DAN METODA \\ Bahan dan alat}

Bahan yang digunakan antara lain limbah serbuk ulin, limbah serbuk bingkirai, limbah serbuk meranti, serbuk sengon, serbuk akasia, kemasan plastk dan tepung kanji. Sedangkan alat yang digunakan dalam penelitian antara lain hammer mill, cetak pellet, press, mixer, crusher, ayakan, kompor, beaker glass, dan pengaduk.

\section{Rancangan Penelitian}

Rancangan penelitian yang digunakan dengan mengkombinasikan beberapa jenis limbah kayu dari moulding dan kayu HTI. Beberapa limbah serbuk kayu yang digunakan antara lain limbah kayu ulin, bengkirai, meranti, serbuk sengon, dan akasia. Adapun kombinasi campuran adalah pada Tabel 1.

Tabel 1. Kombinasi campuran pellet kayu

\begin{tabular}{|c|c|c|c|}
\hline U & UM & MS & UMS \\
\hline M & UB & MA & UMA \\
\hline B & US & BS & BMS \\
\hline S & UA & BA & BSA \\
\hline A & MB & SA & UMBSA \\
\hline
\end{tabular}

Keterangan :

U (ulin), M (Meranti), B (Bengkirai), S (Sengon), A (Akasia)

\section{Tahap-tahap percobaan}

1. Pengumpulan bahan baku berupa limbah kayu, kayu HTI dan tepung tapioka

2. Pemisahan limbah kayu berupa serbuk gergaji dari proses pemotongan dan pembelahan, tatalan dari proses plener dan kayu $\mathrm{HTI}$.

3. Limbah serbuk gergaji dan tatalan dari moulding dijemur untuk mengurangi kadar air yang terikat dalam limbah kayu. Sedangkan kayu HTI dibuat chip lebih dahulu kemudian dijemur mengurangi kadar air yang terikat dalam kayu.

4. Limbah berupa tatalan dan chip kayu dilakukan penyerbukan dengan hammer mill yang telah dilengkapi dengan saringan 60 mesh.

5. Limbah berupa serbuk yang telah diserbuk dengan Hammer mill dan proses pemotongan dan pembelahan dilakukan penyaringan dengan ukuran saringan 60 mesh.

6. Hasil dari penyaringan limbah kayu dikelompokan berdasarkan jenis masing-masing didalam plastik dengan memberikan tanda/kode.

7. Dilakukan penimbangan baik limbah kayu, dan serbuk kayu HTI, tepung tapioka dan air sesuai dengan komposisi campuran yang telah ditentukan.

8. Dilakukan pencampuran serbuk kayu sesuai dengan perlakuan antara air dan tepung tapioka sambil diaduk hingga tercampur secara sempurna.

9. Campuran tepung dan air yang telah dibuat kemudian dipanaskan sambil diaduk hingga membentuk sol lem tepung tapioka. 
10. Pencampuran serbuk limbah kayu ke dalam lem tepung tapioka sambil diaduk hingga merata secara sempurna dengan mengunakan Mixer (adonan pellet). Pencampuran ini juga dapat dilakukan dengan mencampurkan lem tapioka ke dalam limbah serbuk kayu kemudian diaduk hingga tercampur secara sempurna dengan menggunakan Mixer, kemudian dibiarkan kurang lebih 15 menit untuk mendapatkan homogenitas campuran (adonan pellet).

11. Adonan pellet dimasukkan kedalam cetakan pellet.

12. Cetakan yang berisi adonan pellet kemudian diletakkan dimesin press untuk membuat produk pellet kemudian dilakukan pengepresan. Apabila mesin press tidak bergerak lagi maka proses pengepresan dihentikan dan dibarkan \pm 15 menit.

13. Pengepresan dilanjutkan untuk mengeluarkan pellet yang berada dalam cetakan pellet.

14. Penjemuran pellet dapat dilakukan dengan alat pengering (oven) dan sinar matahari.

15. Kombinasi campuran Bahan baku limbah kayu 50 gram, tempung kanji 15 gram dan air 50 gram.

Diagram pembuatan pellet kayu sebagaimana diagram berikut.

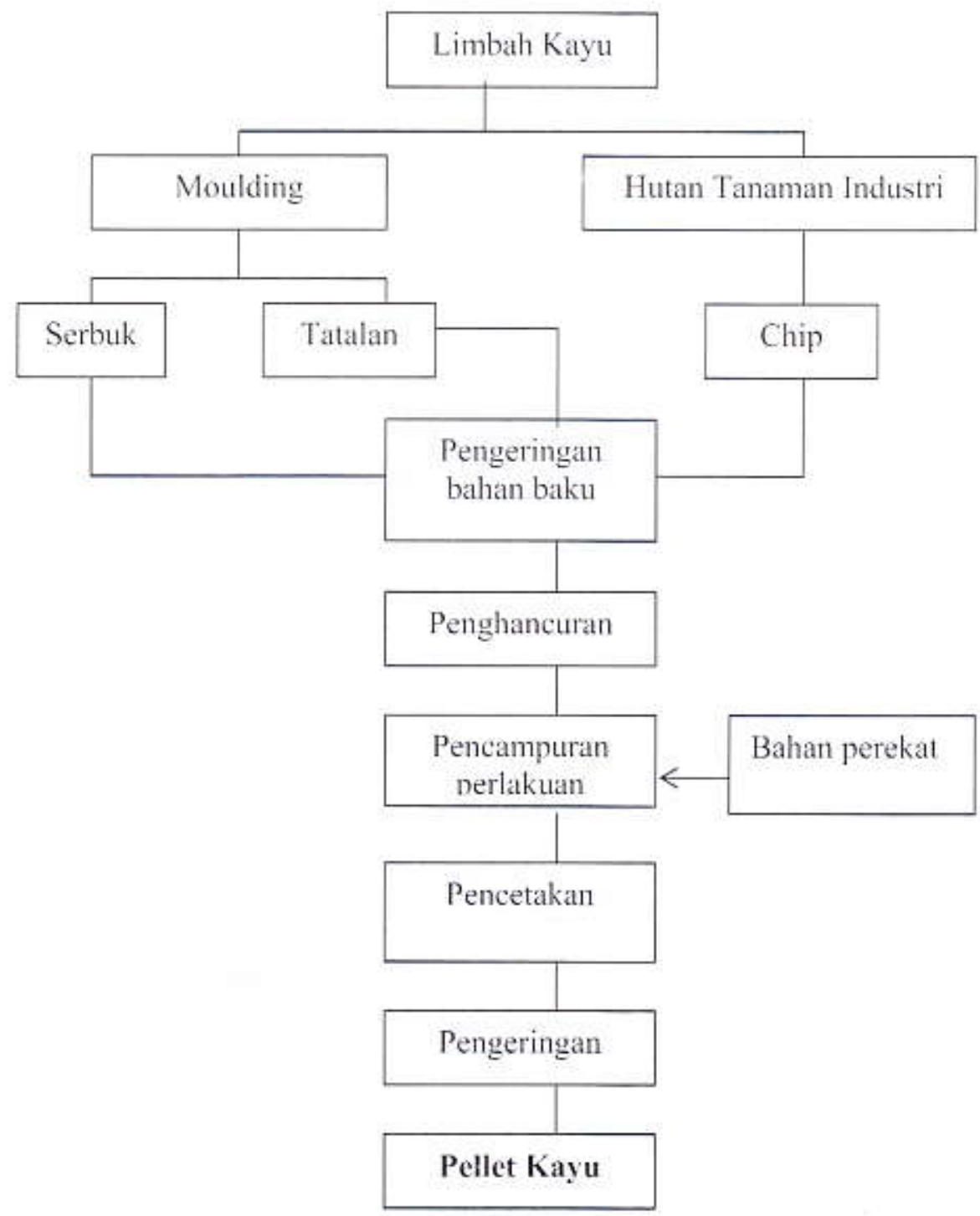

Gambar 1: Diagram alir proses pembuatan pellet kayu 


\section{Parameter Pengujian}

1. Kadar kalori

2. Kadar abu

3. Kadar air

4. Kerapatan

\section{HASIL DAN PEMBAHASAN}

Hasil dari pengujian pellet kayu pada Tabel 2.

Tabel 2. Hasil Penelitian Pallet dari Limbah Serbuk Kayu Ulin, Meranti, Bengkirai. Sengon dan Akasia

\begin{tabular}{|c|c|c|c|c|c|}
\hline \hline No & Sampel & $\begin{array}{c}\text { Kadar Air } \\
(\%)\end{array}$ & $\begin{array}{c}\text { Kerapatan } \\
(\mathrm{gr} / \mathrm{cm})\end{array}$ & Kadar Abu (\%) & Kalori (Cal/gr) \\
\hline 1 & U & 5.62 & 0.73 & 0.15 & 4380 \\
\hline 2 & M & 8.48 & 0.68 & 0.98 & 4287 \\
\hline 3 & B & 9.34 & 0.68 & 0.6 & 4310 \\
\hline 4 & S & 8.61 & 0.62 & 0.8 & 4042 \\
\hline 5 & A & 4.16 & 0.72 & 0.91 & 4221 \\
\hline 6 & UM & 6.28 & 0.75 & 0.22 & 4268 \\
\hline 7 & UB & 8.76 & 0.80 & 0.37 & 4361 \\
\hline 8 & US & 3.46 & 0.52 & 0.65 & 4169 \\
\hline 9 & UA & 4.52 & 0.70 & 0.33 & 4316 \\
\hline 10 & MB & 4.53 & 0.70 & 0.61 & 4263 \\
\hline 11 & MS & 5.59 & 0.52 & 0.65 & 4111 \\
\hline 12 & MA & 4.08 & 0.69 & 0.63 & 4340 \\
\hline 13 & BS & 5.60 & 0.51 & 0.82 & 4125 \\
\hline 14 & BA & 3.57 & 0.70 & 1.08 & 4302 \\
\hline 15 & SA & 2.40 & 0.51 & 0.81 & 4204 \\
\hline 16 & UMS & 6.95 & 0.49 & 0.52 & 4269 \\
\hline 17 & UMA & 3.89 & 0.68 & 0.37 & 4367 \\
\hline 18 & BMS & 7.08 & 0.53 & 0.78 & 4190 \\
\hline 19 & BSA & 3.40 & 0.61 & 0.8 & 4237 \\
\hline 20 & UMBSA & 9.64 & 0.59 & 0.48 & 4280 \\
\hline
\end{tabular}

\section{Kadar Air}

Pada tabel 2 di atas terlihat bahwa nilai kadar air dari 5 jenis kayu dan kombinasinya berkisar antara $2.40 \%-9.64 \%$, lebih jelasnya dapat dilihat pada lampiran gambar 1.

Pada lampiran gambar 1 terlihat nilai kadar air yang sangat variatif dari 5 jenis kayu dan kombinasinya. Hal ini menunjukan bahwa kadar air tidak banyak dipengaruhi oleh kombinasi jenis kayu keras dan lunak, tetapi lebih banyak dipengaruhi oleh kondisi lingkungan dan kadar air permukaan serta bagian tengah pellet yang dihasilkan. Adanya kecenderungan makin kecil kadar air yang terkandung dalam pellet dapat menaikan nilai kerapatan pellet. Sesuai dengan penjelasan Sudrajat (1983) yang menyatakan bahwa bahan baku mempengaruhi terhadap kerapatan suatu produk yang dihasilkan (briket arang) termasuk juga pellet. Diperjelas oleh Ramlah (1998) yang mengatakan bahwa 
kadar air briket arang termasuk pellet erat hubungannya dengan kerapatan, makin tinggi nilai kerapatan maka sifat higroskopis pellet berkurang sehingga daya serap terhadap air dari lingkungannya semakin rendah disebabkan rongga-rongga (porositas) antar partikel semakin rapat sehingga tidak terdapat celah atau rongga kosong.

\section{Kerapatan}

Pada tabel 2 di atas terlihat bahwa nilai kerapatan pallet yang dihasilkan berkisar antara $0.49-0.80 \mathrm{gr} / \mathrm{cm}^{3}$, lebih jelasnya bisa dilihat pada lampiran gambar 2 .

Pada lampiran gambar 2 terlihat nilai kerapatan pallet tertinggi pada kombinasi serbuk kayu ulin dan bengkirai, dan yang terendah pada kombinasi serbuk kayu ulin, meranti dan sengon.

Pada gambar tersebut juga terlihat bahwa nilai kerapatan pallet sangat dipengaruhi oleh jenis serbuk kayunya, dimana kayu yang memiliki kerapatan tinggi seperti kayu ulin, bengkirai dan akasia cenderung menghasilakan kerapatan pallet yang tinggi pula pada saat dikombinasikan, hal yang berbeda terjadi pada saat dikombinasikan dengan kayu yang memiliki kerapatan rendah seperti sengon.

Seperti diketahui bahwa pembuatan pallet kayu adalah melalui pencetakan serbuk kayu lalu ditekan sehingga sangat dipengaruhi oleh ikatan serat yang terjadi. Sesuai dengan pendapat Sudrajat (1983) yang menyatakan bahwa bahan baku sangat mempengaruhi terhadap kerapatan briket arang ataupun pellet yang dihasilkan. Diperjelas Hartoyo (1983) yang menyatakan bahwa berat jenis bahan baku yang digunakan akan mempengaruhi kerapatan briket maupun pellet yang dihasilkan.

\section{Kadar Abu}

Pada tabel 2 di atas terlihat bahwa nilai kadar abu dari pallet yang dihasilkan berkisar antara $0.15-1.08 \%$, lebih jelasnya bisa dilihat pada lampiran gambar 3 .

Berdasarkan lampiran gambar 3 terlihat nilai kadar abu pallet tertinggi pada kombinasi serbuk kayu bengkirai dan akasia, dan yang terendah pada serbuk kayu ulin.

Bervariasinya nilai kadar abu pallet yang dihasilkan menunjukan bahwa kadar abu dipengaruhui banyak faktor, diantaranya komponen kimia kayu yang terkadung seperti zat ekstraktif. Menurut pendapat Soenardi (1976) menyatakan bahwa kandungan mineralmineral yang terdapat pada kayu diikat atau tergabung dengan zat organik atau anorganik dalam bentuk yang tidak dapat larut seperti Kalsium, Potasium, Magnesium merupakan bagian besar dari unsur-unsur logam. Logam-logam ini biasanya terdapat dalam bentuk Karbonat, Fospat, Oksalat, Sulfat, dan Silika. Kandungan silika merupakan unsur-unsur utama terbentuknya dalam abu.

\section{Nilai Kalori}

Pada tabel $2 \mathrm{di}$ atas terlihat bahwa nilai kalori pallet yang dihasilkan berkisar antara $4042-4380 \mathrm{cal} / \mathrm{gram}$, lebih jelasnya dapat dilihat pada lampiran gambar 4 berikut.

Berdasarkan lampiran gambar 4 terlihat nilai kadar abu pallet tertinggi pada serbuk kayu ulin dan terrendah pada serbuk kayu sengon.

Tinggi rendahnya nilai kalori dipengaruhui banyak faktor, diantaranya kerapatan kayu. Kayu-kayu yang memiliki kerapatan tinggi cenderung menghasilkan nilai kalori yang tinggi pula.

Berdasarkan dari nilai kalor yang dihasilkan dari komposisi tunggal dan kombinasi campuran tidak ada perbedaan yang mencolok yaitu kurang dari $5000 \mathrm{kal} / \mathrm{gram}$, namun hal itu dapat dilihat nilai kalor dari yang tetinggi adalah pellet dari limbah ulin dan yang terendah dari limbah sengon, hal ini terlihat pada lampiran gambar 4.

Pellet limbah kayu ulin menghasilkan nilai kalor tertinggi dibandingkan dengan limbah kayu yang lain, hal ini disebabkan berat jenis kayu ulin lebih tinggi dibandingkan dengan limbah kayu yang lain bengkirai, akasia, meranti dan sengon. Selain besarnya nilai kalor dipengaruhi oleh berat jenis kayu juga dipengaruhi oleh kandungan lignin, dan zat ekstraktif. 
Pada dasarnya semua jenis pohon dapat dijadikan sebagai sumber energi, tetapi tiap-tiap jenis mempunyai nilai kalor yang berbeda-beda yang ditentukan oleh besar kecilnya berat jenis. Berat jenis kayu berbanding lurus dengan nilai kalornya. Semakin tinggi berat jenisnya semakin tinggi pula nilai kalornya. Hal ini dapat dilihat dari lampiran gambar 4, bahwa nilai kalor ulin lebih tinggi dari bengkirai, meranti, akasia dan sengon.

Menurut Komarayati dan Gusmalina, 1994 menyatakan bahwa Variasi nilai kalor dipengaruhi oleh kadar lignin dan zat ekstraktif. Kadar lignin yang tinggi pada kayu akan meningkatkan nilai kalor kayu tersebut. Sedangkan kadar zat ekstraktif tergantung pada mudah dan tidak zat ekstraktif tersebut terbakar. Hudaya (1989) juga mengemukakan bahwa nilai kalor sangat dipengaruhi oleh kadar lignin dan zat ekstraktif. Kadar liginin yang tinggi akan meningkatkan nilai kalor hal ini terjadi pada pellet yang terbuat dari ulin. dan bengkirai.

Bahan perekat dan tekanan pengempaan turut mempengaruhi nilai kalor yang dihasilkan. Sudradjat (1983), bahwa bahan baku, bahan perekat dan tekanan pengempaan sangat berpengaruh terhadap nilai kalor yang dihasilkan. Bahan perekat tapioka cenderung dapat menambah nilai kalor yang lebih tinggi.

Nilai kalor berguna untuk efisiensi artinya apabila nilai kalor persatuan berat rendah berarti jumlah bahan bakar yang dipergunakan untuk proses pembakaran atau pemanasan akan lebih banyak, tetapi jika nilai kalor tinggi berarti jumlah bahan bakar yang diperlukan untuk proses pembakaran atau pemanasan menjadi lebih sedikit. (Anonim, 1986).

\section{2.5. Sifat dan kualitas pellet}

Untuk melihat sifat dan kualitas pellet memungkinkan dibandingkan dengan standar kualitas briket arang yang distandarkan dengan negara-negara pengimpor sebagaimana pada Tabel 3 .

Tabel 3. Sifat dan kualitas briket arang sebagai pembanding untuk pellet.

\begin{tabular}{|c|c|c|c|c|c|}
\hline Parameter & $\begin{array}{c}\text { Sampel } \\
\text { pellet }\end{array}$ & Amerika & Jepang & Inggris & SNI \\
\hline $\begin{array}{c}\text { Kadar air } \\
(\%)\end{array}$ & $2,40-9,64$ & 6 & $6-8$ & $3-4$ & 6 \\
\hline $\begin{array}{c}\text { Kerapatan } \\
(\text { gricm })\end{array}$ & $0,49-0,80$ & 1 & $1-2$ & 0,84 & $>0,7$ \\
\hline $\begin{array}{c}\text { Kadar abu } \\
(\%)\end{array}$ & $0,15-1,08$ & $1-8$ & $3-6$ & $8-10$ & $<8$ \\
\hline $\begin{array}{c}\text { Kadar kalor } \\
\text { Kal/gr) }\end{array}$ & $4042-4380$ & 6500 & $6000-7000$ & 6500 & $>6000$ \\
\hline
\end{tabular}

Sumber: Sudrajat (1983)

Secara umum berdasarkan data pada tabel 3, bahwa kualitas pellet yang dihasilkan memenuhi standar yang dipersyaratkan keculai kadar kalor (nilai kalor).

\section{Kadar air}

Nilai rataan kadar air pellet secara umum telah memenuhi standar dari empat negara kecuali untuk pellet dari limbah kayu bengkirai, meranti, sengon, kombinasi campuran antara ulin dan bengkirai, dan kombinasi campuran antara ulin, meranti, bengkirai, sengon, dan akasia (tabel 2) untuk standar Jepang (tabel 3). Hal ini disebabkan penggunaan air pada saat pembuatan lem perekat tapioka diduga berlebihan. Pellet yang dihasilkan dari penelitian memenuhi kualitas arang untuk bahan bakar rumah tangga $<8 \%$ (Anonim, 1982) dan kualitas briket arang (Anonim, 1978) sebesar $6 \%$.

\section{Kerapatan}

Nilai rataan kerapatan pellet secara umum telah memenuhi standar dari empat negara untuk kualitas briket arang (tabel 3). Pada saat pembuatan pellet menggunakan 
tekanan 15 bar, sehingga dapat digunakan sebagai acuan untuk pembuatan pellet secara komersial.

\section{Kadar abu}

Nilai rataan kadar abu pellet secara umum telah memenuhi standar dari empat negara untuk kualitas briket arang (tabel 3). Limbah kayu ulin, bengkirai, meranti, akasia, dan sengon memungkinkan sebagai bahan bakar alternatif karena memenuhi standar untuk kadar abu.

\section{Kadar kalor}

Nilai rataan kadar kalor secara umum belum memenuhi standar kualitas briket arang (tabel 3). Hal ini diduga bahan limbah kayu tidak melalui proses karbonisasi. Untuk meningkatkan kadar kalor memungkinkan dinaikan tekanan dalam pengepresan pembuatn pellet diatas 15 bar, sehingga pellet dalam keadaan rapat dalam rangka menaikan tingkat kerapatan pellet.

\section{KESIMPULAN DAN SARAN}

\section{Kesimpulan}

1. Nilai kerapatan, kadar abu dan nilai kadar air secara umum memenuhi standar empat negara Amerika, Jepang, Ingggris dan Indonseia.

2. Nilai kalor belum memenuhi standar empat negara Amerika, Jepang, Ingggris dan Indonseia.

3. Kombinasi campuran terbaik dihasilkan antara limbah kayu ulin dengan bengkirai. Kombinasi campuran yanag lain antara ulin, meranti, dan akasia.

\section{Saran}

Untuk meningkatkan kadar kalor perlu dinaikkan tekanan pengepresan diatas 15 bar dan perlu diperhatikan dalam penambahan jumlah air untuk pembuatan lem tepung tapioka agar kadar air dapat memenuhi standar.

\section{DAFTAR PUSTAKA}

Anonim, 1982. Feasybility Study Industri Briket Arang di Transmigrasi IV Sangkulirang dan Muara Wahau. Laporan Kerjasama Balai Penelitian Hasil Hutan Bogor dengan Fakultas Kehutanan Universitas Mulawarman. Samarinda.

Anonim, 1986. Penelitian Pengembangan Pembuatan Prototype Alat Briket Arang. Balai Penelitian dan Pengembangan Industri Banjarbaru.

Hartoyo, 1983. Pembuatan Arang dan Briket Arang Secara Sederhana dari Serbuk Gergaji dan Limbah Industri Perkayuan. Pusat Penelitian dan Pengembangan Hasil Hutan. Bogor.

Hudaya, N. dan Hartoyo, W. Made, 1989. Hasil Destilasi Kering Nilai Kalor dari Beberapa Jenis Kayu HTI. Proceding Diskusi Sifat dan Kegunaan Jenis Kayu HTI. Badan Litbang Kehutanan. Depatemen Kehutanan. Jakarta.

Gusmalina dan Komarayati S, 1994. Pembuatan Arang dan Briket Arang dari Kayu Manis (Cinnamomum burmanii Ness ex. BL) dan Kayu Sukun (Artocarpus altis Parkinson). Jurnal Penelitian Hasil Hutan vol. 12 no. 6. 
Ramlah, 1998. Pengaruh Jumlah Perekat Terhadap Kualitas Briket Arang dan Campuran Serbuk Arang Kayu Jenis Kapur (Dryobalanops spp) dengan Sekam Padi. Skripsi. Fakultas Kehutanan. Universitas Mulawarman. Samarinda.

Sudrajat R, 1983. Pengaruh Bahan Baku, Jenis Perekat dan Tekanan Kempa terhadap Kualitas Briket Arang. Laporan No. 165. Pusat Penelitian dan Pengembangan Hasil Hutan Bogor. Bogor.

Soenardi. 1976. Sifat-Sifat Kimia Kayu. Yayasan Fakultas Kehutanan Universitas Gajah Mada. Yogyakarta.

\section{LAMPIRAN}

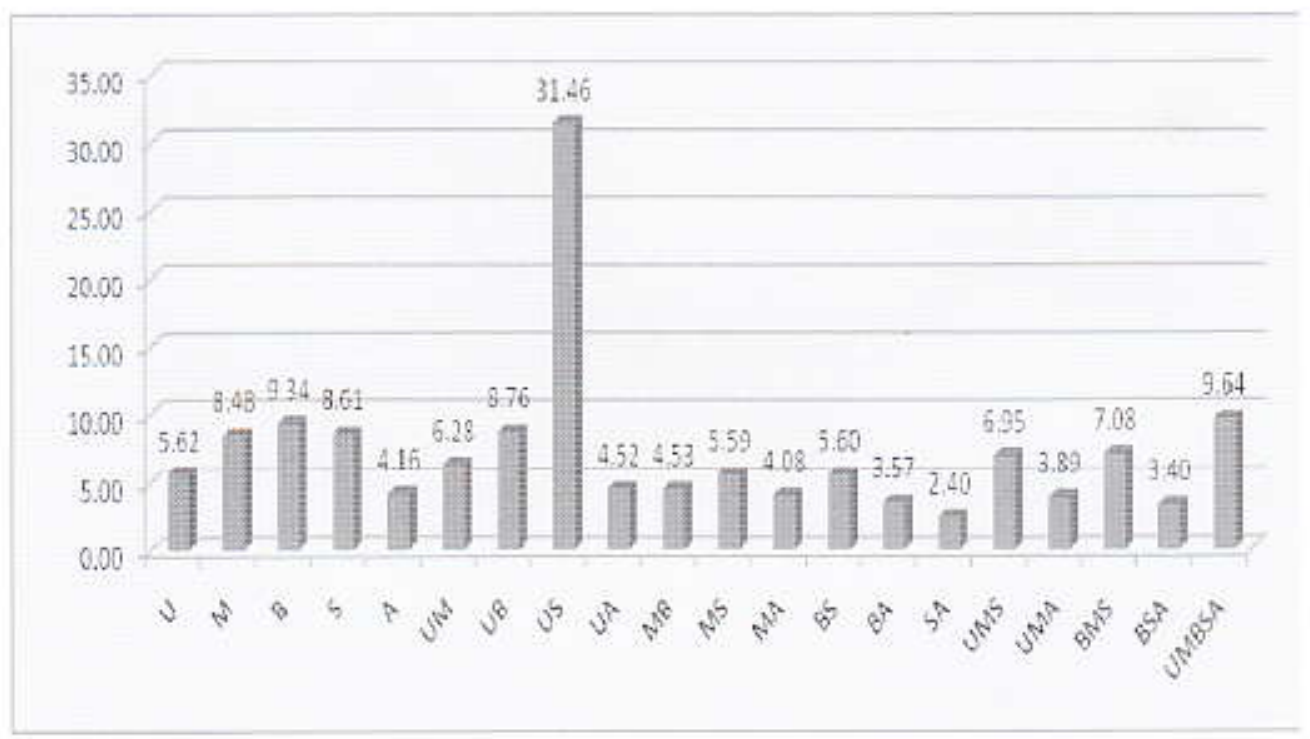

Gambar 1. Grafik Nilai Kadar Air Pellet

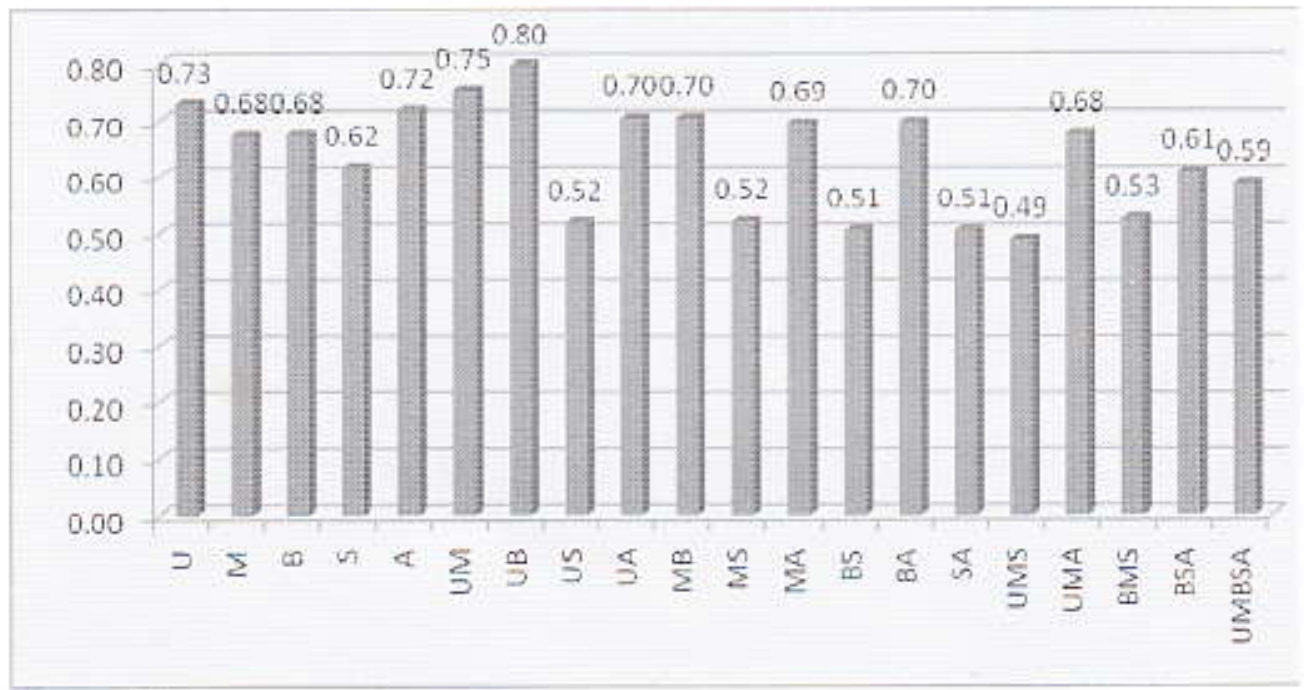

Gambar 2. Grafik Nilai Kerapatan Pallet 


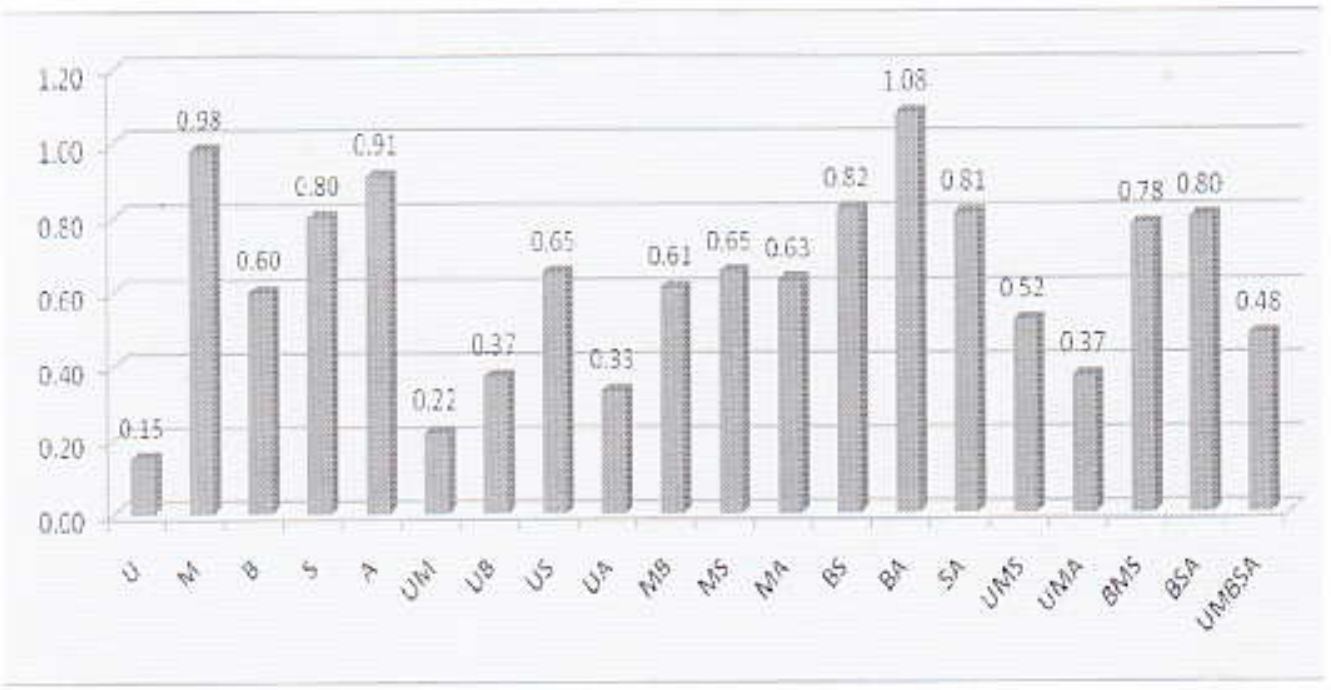

Gambar 3. Grafik Kadar Abu Pellet

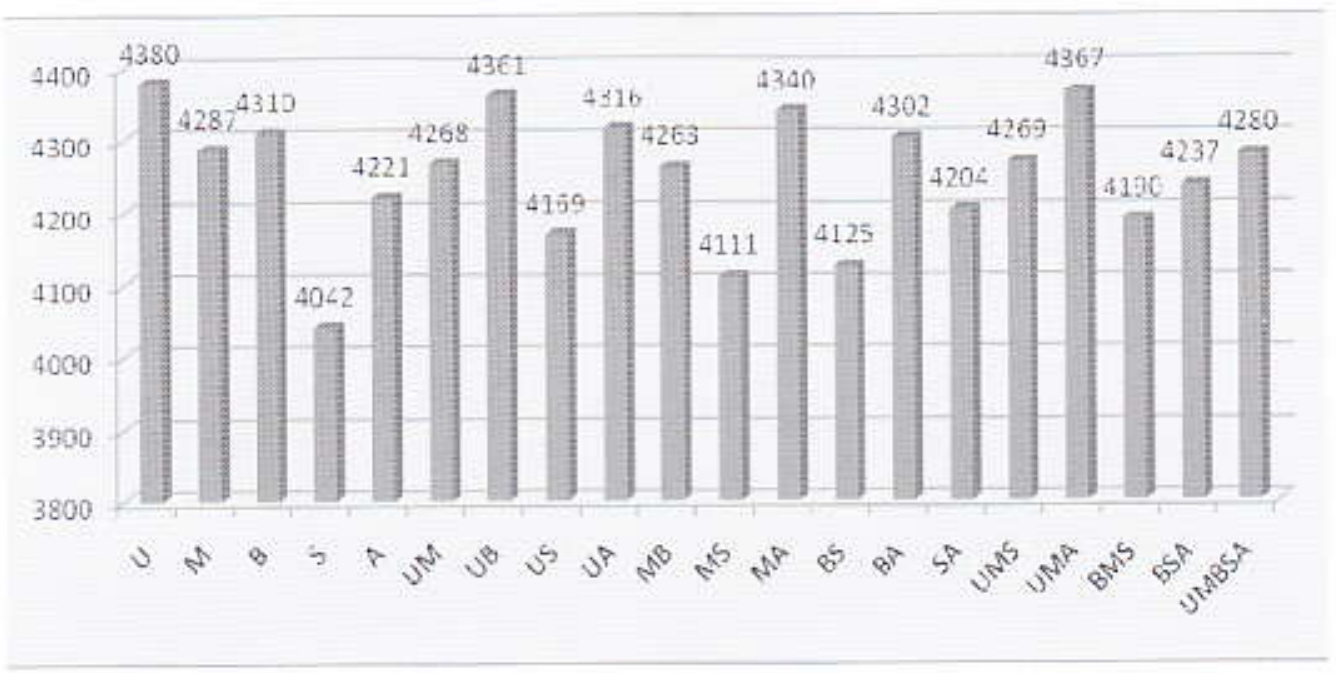

Gambar 4. Grafik Nilai Kalori Pallet 